\title{
Analisis Faktor-Faktor Yang Mempengaruhi Literasi Keuangan Pada Petani Tanaman Pangan dan Holtikultura di Kabupaten Maros Sulawesi Selatan
}

\author{
Anas Iswanto Anwar", Rezki Putri, Sabir \\ Fakultas Ekonomi dan Bisnis, Universitas Hasanuddin, Makassar, Indonesia \\ J1. Perintis Kemerdekaan KM.10, Tamalanrea Indah, Kec. Tamalanrea, Kota Makassar, Sulawesi Selatan 90245 \\ E-mail: aianwar@fe.unhas.ac.id
}

\begin{abstract}
Abstrak
Penelitian ini bertujuan untuk mengetahui besarnya pengaruh karakteristik demografi terhadap tingkat literasi keuangan petani tanaman pangan dan holtikultura di Kecamatan Camba Sulawesi Selatan. Data penelitian ini diperoleh dari kuesioner (primer) dan beberapa observasi serta wawancara langsung dengan petani di kecamatan camba Sulawesi Selatan. Penelitian ini menggunakan metode analisis regresi linier berganda. Hasil analisis menyimpulkan bahwa variabel karakteristik demografi yang terdiri dari tingkat pendapatan, usia, tingkat pendidikan, dummy preferensi risiko, dan jarak ke lembaga keuangan secara simultan berpengaruh signifikan terhadap variabel literasi keuangan dengan tingkat signifikansi lima persen. Tingkat pendapatan, tingkat pendidikan, preferensi risiko secara parsial berpengaruh positif dan signifikan terhadap variabel literasi keuangan. Jarak ke lembaga keuangan berpengaruh negatif dan signifikan sedangkan usia tidak berpengaruh signifikan terhadap variabel literasi keuangan. Sebesar 43,8 persen variasi dalam variabel literasi keuangan dijelaskan oleh variabel bebas yang digunakan dalam model ini, sisanya sebesar 56,2 persen dijelaskan oleh variabel- variabel lainnya.
\end{abstract}

Kata Kunci: literasi keuangan, tingkat pendapatan, usia, tingkat pendidikan, jarak dummt, preferensi risiko.

\begin{abstract}
This study aims to determine the effect of demographic characteristics on the level of financial literacy of food crops and horticulture farmers in Camba sub-district in South Sulawesi Province. This research data obtained from the questionnaire (primary) and few observations and direct interviews with Camba sub-district farmers. This study uses a multiple linear regression analysis method. The results of the analysis concluded that the demographic characteristic variables consisting of income level, age, education level, risk preference dummy, and distance to financial institutions simultaneously had a significant effect on financial literacy variables with a five percent significance level. Income level, education level, risk preference partially had a positive and significant effect on the variable financial literacy. Distance to financial institutions had a negative and significant effect while age doesn't have a significant effect on financial literacy. Of 43.8 percent from the variation in financial literacy variables is explained by the independent variables used in this model, while the rest of 56.2 percent is explained by other variables.
\end{abstract}

Keywords: financial literacy, income level, age, education level, distance, risk preference dummy.

\section{Pendahuluan}

Sektor keuangan merupakan sektor penting penyumbang produk domestik bruto (PDB). Sektor keuangan juga penting karena sektor ini dapat mempengaruhi pertumbuhan sektorsektor lainnya. Sehingga untuk mendorong peran sektor keuangan ikut serta dalam pertumbuhan dan pembangunan ekonomi Indonesia, Bank Indonesia, Otoritas Jasa Keuangan (OJK), dan pemerintah bekerja sama meningkatkan tingkat literasi keuangan masyarakat. Literasi keuangan mendapat perhatian lebih di negara-negara maju mencerminkan bahwa literasi keuangan menjadi pokok kajian yang penting.

Literasi keuangan adalah tingkat pengetahuan masyarakat dalam mengetahui produk, jasa, dan lembaga keuangan yang diukur dalam suatu indeks yang disebut indeks literasi keuangan. Semakin tinggi tingkat pengetahuan masyarakat akan lembaga keuangan akan meminimalisir tindak kejahatan dalam sektor keuangan dan perbankan (financial crime). Kejahatan finansial yang sering terjadi seperti beragamnya produk dan jasa keuangan yang tidak jelas serta investasi yang bersifat ilegal oleh oknum yang ingin mendapatkan keuntungan secara instan. Umumnya yang terjebak dalam kejahatan finansial tersebut adalah masyarakat yang memiliki tingkat literasi yang rendah. Selain bermanfaat untuk masyarakat pribadi, meningkatkan tingkat literasi keuangan untuk memajukan sektor industri jasa keuangan dan perbankan karena masyarakat merupakan pengguna utama jasa lembaga keuangan. Dalam penggunaan produk dan jasa keuangan, literasi dan inklusi keuangan akan menciptakan efek multiplier yang kemudian dapat mendorong lembaga keuangan berinovasi menciptakan produk dan jasa keuangan (Yushita, 2017).

Berdasarkan Survei Nasional Literasi dan Inklusi Keuangan (SNLIK) OJK yang dilaksanakan pada tahun 2016, literasi keuangan di Indonesia masih terlihat rendah. Indeks literasi keuangan Indonesia tahun 2016 sebesar 29,66 persen dimana daerah dengan indeks literasi yang tinggi masih didominasi oleh daerah kawasan Jawa dan Bali. Jika dibandingkan dengan indeks inklusi keuangan Indonesia tahun 2016 yang sudah mencapai 67,82 persen, indeks literasi keuangan Indonesia tertinggal jauh. Terdapat gap sebesar 38,16 persen antara tingkat inklusi dengan literasi keuangan masyarakat. Artinya sebanyak 38,16 persen masyarakat Indonesia telah mendapatkan akses terhadap lembaga keuangan tetapi tingkat pengetahuan dan pemahaman akan jasa dari lembaga keuangan tersebut masih rendah.

\footnotetext{
* Corresponding author
} 
Indeks literasi keuangan di Sulawesi Selatan sendiri pada tahun 2016 masih tercatat cukup rendah dengan perolehan angka indeks sebesar 28,36 persen. Angka tersebut masih dibawah angka indeks literasi keuangan nasional 2016 yaitu sebesar 29,66 persen. Sama dengan nasional, indeks literasi keuangan Sulawesi Selatan juga tertinggal jauh dari indeks inklusi keuangannya yang sudah mencapai 68 persen di atas indeks inklusi keuangan nasional (OJK, 2016).

Badan Pusat Statistik (BPS) menyatakan bahwa salah satu penyumbang terbesar PDB Indonesia adalah sektor pertanian. Menurut Firdaus dan Sunarti (2009) pelaku utama sektor tersebut adalah rumah tangga petani yang pada umumnya memiliki pendapatan yang rendah dan tergolong keluarga miskin. Literasi keuangan pada petani memainkan peranan penting dalam manajemen keuangan petani. Sumber pembiayaan pada sektor pertanian dipasok oleh sumber keuangan formal dan informal. Rendahnya tingkat literasi keuangan petani menyebabkan lebih banyak ketergantungan pada sektor pembiayaan informal yang mungkin lebih mahal (Ravikumar et al., 2013).

Menurut Anwar dkk (2006) kawasan pedesaan di provinsi Sulawesi Selatan merupakan kawasan yang identik dengan masyarakat pertanian tradisional, yang dekat dengan masalah keterbelakangan dan kemiskinan. Dimana di kawasan tersebut masih terbatas keberadaan lembaga keuangan. Terbatasnya keberadaan lembaga keuangan akan berkaitan dengan tingkat pengetahuan/literasi keuangan masyarakat. Masyarakat yang telah mengetahui lembaga jasa keuangan, terampil dalam memanfaatkan produk dan jasa keuangan, serta memiliki keyakinan akan lembaga jasa keuangan perlu didukung dengan ketersediaan akses kepada lembaga, produk, dan layanan jasa keuangan yang dapat memudahkan masyarakat mengimplementasikan pengetahuan keuangan yang dimiliki.

Kecamatan Camba merupakan salah satu kecamatan di Kabupaten Maros Provinsi Sulawesi Selatan yang jumlah penduduknya sebagian besar bekerja pada sektor pertanian, khususnya padi sawah dan tanaman holtikultura menjadi mata pencaharian utama penduduk.

Rendahnya tingkat literasi keuangan petani, banyaknya jumlah kelompok keluarga tani di Kecamatan Camba, dan kurangnya penelitian mengenai faktor-faktor yang mempengaruhi literasi keuangan pada petani Indonesia khususnya pada petani di Provinsi Sulawesi Selatan menjadi inti pokok latar belakang pengajuan penelitian.

Dari uraian permasalahan dalam latar belakang di atas, maka rumusan masalah dalam penelitian ini adalah sebagai berikut: Apakah tingkat pendapatan, usia, tingkat pendidikan, preferensi risiko, jarak tempat tinggal ke lembaga keuangan terdekat berpengaruh signifikan terhadap tingkat literasi keuangan pada petani tanaman pangan dan holtikultura di Kecamatan Camba Kabupaten Maros?

\section{Kajian Teori}

\section{Pengertian dan Aspek-Aspek Literasi Keuangan}

Menurut Krisna et al. literasi keuangan membantu suatu individu agar dapat terhindar dari masalah keuangan dan dengan adanya literasi keuangan masyarakat mampu mengalokasikan keuangan mereka dengan baik. Dengan adanya bantuan lembaga keuangan untuk membantu masyarakat dalam manajemen keuangan serta memanfaatkan program-program seperti investasi dan penggunaan kredit (Giffari, 2018). Literasi keuangan untuk meningkatkan kepekaan masyarakat terhadap sektor jasa keuangan, yang dimulai dengan mengetahui kemudian meyakini, hingga menjadi terampil untuk terlibat aktif, dengan kata lain mencapai masyarakat yang well literate (terliterasi dengan baik) pada sektor jasa keuangan, yakni bidang perbankan, perasuransian, lembaga pembiayaan, dana pensiun, pasar modal, dan pegadaian (Yuwono dkk, 2017).

Otoritas Jasa Keuangan (OJK) menjelaskan bahwa literasi keuangan tidak terbatas pada pengertian pengetahuan, keterampilan dan keyakinan akan lembaga, produk dan layanan jasa keuangan semata, namun sikap dan perilaku masyarakat dapat memberikan pengaruh dalam meningkatkan literasi keuangan yang selanjutnya dapat mendorong terwujudnya kesejahteraan masyarakat. Sikap dan perilaku keuangan yang bijak tercermin dalam kemampuan seseorang menentukan tujuan keuangan, menyusun perencanaan keuangan, mengelola keuangan dan mampu mengambil keputusan keuangan yang berkualitas dalam menggunakan produk dan layanan jasa keuangan (OJK, 2017). Menurut OJK literasi keuangan adalah rangkaian proses atau aktivitas untuk meningkatkan pengetahuan (knowledge), keterampilan (skill), dan keyakinan (confidence) konsumen serta masyarakat luas sehingga mereka mampu mengelola keuangan pribadi dengan baik (Yarasevika, 2016). Misi penting dari program literasi keuangan adalah untuk melakukan edukasi di bidang keuangan kepada masyarakat Indonesia agar masyarakat dapat mengelola keuangan secara cerdas. Rendahnya pengetahuan masyarakat tentang industri jasa keuangan kemudian dapat diatasi dan masyarakat tidak mudah tertipu dengan produk-produk investasi yang menawarkan keuntungan tinggi dalam jangka pendek tanpa mempertimbangkan risikonya (OJK, 2015).

Remund (2010) menyatakan bahwa literasi keuangan merupakan pengukuran terhadap pemahaman seseorang mengenai konsep keuangan, dan memiliki kemampuan dan keyakinan untuk mengatur keuangan pribadi melalui pengambilan keputusan jangka pendek yang tepat, perencanaan keuangan jangka panjang, serta memperhatikan kejadian dan kondisi ekonomi dalam memahami literasi keuangan. Remund menyatakan ada empat hal yang paling umum dibahas dalam literasi keuangan yaitu 1) penganggaran, 2) tabungan, 3) pinjaman, dan 4) investasi. Ketika seseorang mendapatkan pendapatan, maka harus ada penganggaran yang disisihkan untuk tabungan atau investasi. Apabila dapat dilaksanakan dengan baik maka tidak memerlukan uang tambahan dengan mencari pinjaman/hutang karena telah dapat melakukan pengelolaan keuangan dengan baik.

Sedangkan menurut Chen and Volpe (1998) literasi keuangan adalah kemampuan seseorang dalam mengelola keuangan agar hidup lebih sejahtera di masa yang akan datang. Chen and Volpe membagi literasi keuangan dalam empat aspek yaitu 1) General Personal Finance Knowledge, bagian ini meliputi pemahaman beberapa hal yang berkaitan dengan pengetahuan dasar tentang keuangan pribadi, 2) Saving and borrowing, bagian ini meliputi pengetahuan yang berkaitan dengan tabungan dan pinjaman seperti penggunaan kartu kredit, 3) Insurance, bagian ini meliputi pengetahuan dasar 
asuransi dan produk-produk asuransi seperti asuransi jiwa dan asuransi kendaraan bermotor, 4) Investment, bagian ini meliputi pengetahuan tentang suku bunga pasar, reksadana dan risiko investasi.

\section{Indeks dan Klasifikasi Literasi Keuangan}

Menurut Organisation for Economic Co- operation and Development (OECD) International Network on Financial Education (INFE) (Atkinson and Messy, 2012) indeks literasi keuangan adalah nilai yang diukur berdasarkan tiga komponen dari literasi keuangan, yaitu:

1. Pengetahuan finansial (financial knowledge).

2. Perilaku finansial (financial behaviour).

3. Sikap finansial (financial attitudes).

\section{Hipotesis Penelitian}

\section{Kerangka pemikiran}

Berdasarkan perumusan dan tujuan masalah maka disusun hipotesis penelitian sebagai berikut: Tingkat pendapatan, usia, tingkat pendidikan, dan preferensi risiko berpengaruh positif dan signifikan terhadap tingkat literasi keuangan petani tanaman pangan dan holtikultura di Kecamatan Camba. Sedangkan jarak ke lembaga keuangan berpengaruh negatif dan signifikan terhadap tingkat literasi keuangan petani tanaman pangan dan holtikultura di Kecamatan Camba.

\section{Metode}

\section{Populasi dan Sampel}

Populasi dalam penelitian ini adalah seluruh petani di Kecamatan Camba yang berprofesi sebagai petani tanaman pangan dan holtikultura. Sampel penelitian diperoleh dengan metode teknik probability sampling yaitupengambilan sampel random secara acak yang memberikan peluang yang sama bagi setiap unsur atau anggota populasi untuk dipilih menjadi anggota sampel. Metode pengambilan sampel dilakukan secara cluster random sampling dengan memilih tiga desa/kelurahan sebagai lokasi pengambilan sampel. Desa/kelurahan terpilih adalah Kelurahan Cempaniga, Desa Sawaru, dan Desa Benteng dengan pertimbangan jarak desa/kelurahan tersebut ke lembaga keuangan. Kelurahan Cempaniga memiliki jarak paling dekat dengan lembaga keuangan karena merupakan ibukota kecamatan. Desa Sawaru memiliki jarak pertengahan dari ibukota kecamatan dan Desa Sawaru merupakan desa yang memiliki kelompok keluarga petani terbesar di Kecamatan Camba. Sedangkan Desa Benteng memiliki jarak yang paling jauh dari ibukota kecamatan.

Untuk menentukan besarnya sampel menggunakan teori sampling menurut Arikunto (2006) yang menyatakan bahwa apabila populasi penelitian berjumlah kurang dari seratus maka sampel yang diambil adalah semua anggota populasi. Namun apabila populasi penelitian berjumlah lebih dari seratus maka sampel dapat diambil antara sepuluh sampai lima belas persen atau dua puluh sampai 25 persen atau lebih dari jumlah populasi. Maka dari jumlah populasi, sampel diambil sepuluh persen dari populasi, yaitu sepuluh persen dari 2.194 kelompok keluarga petani. Menurut Sekaran (2006) ukuran sampel penelitian pada umumnya adalah sebanyak 30 sampai dengan 500. Menurut Sekaran ukuran tersebut juga dinilai telah cukup representatif pada populasi.
Jadi jumlah keseluruhan sampel sebanyak 219 kelompok keluarga petani dari tiga wilayah pengambilan sampel. Kemudian 219 sampel dibagi tiga maka pengambilan sampel sebesar 73 responden pada tiap masing- masing wilayah pengambilan sampel.

\section{Jenis dan Sumber Data}

Jenis data yang akan digunakan dalam penelitian ini adalah data primer dan sekunder. Data sekunder berupa data jumlah populasi petani tanaman pangan dan holtikultura di Kecamatan Camba, yang diperoleh di UPTD-BPP Kecamatan Camba. Data primer berupa data tingkat pendapatan, usia, tingkat pendidikan, preferensi risiko, jarak ke lembaga keuangan, dan tingkat literasi keuangan petani yang diperoleh melalui pengisian kuesioner dan hasil wawancara lansung kepada petani yang dijadikan sampel penelitian. Kuesioner disebarkan secara random yang mana di dalamnya terdapat 34 pertanyaan yang terkait dengan tiga komponen indeks literasi keuangan. Pertanyaan pada kuesioner penelitian berdasarkan rujukan pada kuesioner penelitian Giffari (2018) dan Yarasevika (2016)

\section{Model Analisis Analisis Deskriptif}

Untuk melihat seberapa besar literasi keuangan responden, data didapatkan dari seberapa besar nilai yang responden dapatkan dari menjawab pertanyaan yang diberikan. Dengan metode scoring, jawaban yang benar dihitung dan dibagi dengan seluruh pertanyaan kemudian dikali dengan seratus persen. Setiap satu pertanyaan yang dijawab benar akan mendapat nilai sebesar satu dan jika dijawab salah akan mendapat nilai sebesar nol (Mabyakto, 2017).

Tingkat literasi keuangan petani diukur dengan indeks yang dibangun dari hasil jawaban serangkaian pertanyaan terkait tiga komponen literasi keuangan.

$$
\begin{aligned}
& I L K=\frac{\text { Jumlah jawabanbenar }}{\text { Jumlah pertanyaan }} \times 100 \\
& \frac{\text { Indeks X1+Indeks X2+Indeks X3 }}{3}
\end{aligned}
$$

dimana:

ILK = Indeks Literasi Keuangan,

Indeks $\mathrm{X} 1=$ Indeks pengetahuan finansial (financial knowledge),

Indeks X2 = Indeks perilaku finansial (financial behaviour), Indeks X3 = Indeks sikap finansial (financial attitudes).

Berdasarkan teori Chen and Volpe (1998), hasil perhitungan tersebut kemudian akan dibagi menjadi tiga kelompok kriteria tingkat literasi keuangan, yaitu:

1. Indeks literasi keuangan $<60 \%$ yang berarti individu memiliki pengetahuan tentang keuangan yang rendah.

2. Indeks literasi keuangan 60\%-79\% yang berarti individu memiliki pengetahuan tentang keuangan yang sedang.

3. Indeks literasi keuangan $>80 \%$ yang berarti individu memiliki pengetahuan keuangan yang tinggi.

\section{Analisis Regresi Linear Berganda}

Model umum regresi linear berganda untuk penelitian ini adalah: 
$\mathrm{Y}=\mathrm{a}+\mathrm{b} 1 \mathrm{X} 1+\mathrm{b} 2 \mathrm{X} 2++\mathrm{bn} \mathrm{Xn}+\varepsilon$

Hubungan fungsional pada persamaan (1) di atas selanjutnya dapat dituliskan dalam suatu persamaan berikut:

$\mathrm{ILK}=\beta 0+\beta 1$ pendapatan $+\beta 2$ umur $+\beta 3$ tingkat pendidikan $+\beta 4$ dummy preferensi risiko $+\beta 5$ jarak $+\varepsilon$

Dimana :

ILK $=$ Indeks literasi keuangan petani $\beta 1, \beta 2, \beta 3, \beta 4=$ Parameter

$\beta 0=$ Intercept/Konstanta

$\mathrm{O}_{!}=$Tingkat pendapatan petani (rupiah/ bulan)

$\mathrm{O}=$ Usia petani (tahun)

$\mathrm{O}_{\#}=$ Tingkat pendidikan petani

(tahun)

$\mathrm{O}_{\S}=$ Dummy preferensi risiko

$\mathrm{O}_{\%}=$ Jarak rumah petani ke lembaga keuangan terdekat $(\mathrm{km})$

$\varepsilon=$ Error term Pengujian Hipotesis

Sebagai dasar pengambilan keputusan dalam hasil pengujian hipotesis untuk melihat tingkat signifikansi dari koefisien regresi antar variabel bebas terhadap variabel terikat, maka akan dilakukan beberapa pengujian yaitu Uji Statistik t, Uji Statistik F, dan Menghitung Koefisien Determinasi $\left(\mathrm{R}^{2}\right)$.

\section{Hasil dan Pembahasan}

\section{Tingkat Literasi Keuangan}

Hasil analisis menunjukkan bahwa rata-rata mayoritas petani dari tiga lokasi penelitian termasuk pada kategori literasi keuangan yang rendah yaitu sebesar 122 responden dari

219 sampel atau 55,71 persen. Sementara untuk kategori literasi keuangan sedang atau cukup terliterasi sebesar 84 responden atau 38,36 persen dan untuk kategori literasi keuangan tinggi hanya sebesar tiga belas responden atau 5,94 persen saja.

Responden yang memiliki literasi keuangan yang baik menunjukkan bahwa responden tersebut memiliki pengetahuan keuangan yang cukup, dapat mengelola manajemen keuangan dengan baik, dapat menggunakan produk dan jasa keuangan lebih banyak seperti menabung, membeli premi asuransi, berinvestasi, memperoleh kredit, dan lain sebagainya. Responden yang memiliki literasi keuangan yang cukup akan lebih mudah memahami hal-hal yang terkait dengan industri jasa keuangan serta memiliki informasi dalam mengakses industri jasa keuangan yang diperlukan dalam keseharian masyarakat. Hal tersebut memungkinkan responden tersebut lebih mudah dalam menentukan produk dan layanan jasa keuangan yang sesuai dengan kebutuhan dan kemampuan mereka. Selain itu, responden dengan literasi keuangan yang cukup akan terhindar dari risiko keuangan.

Hasil analisis juga menunjukkan tingkat literasi keuangan petani di Kecamatan Camba berdasarkan pembagian di tiga wilayah sampel. Di wilayah ibu kota kecamatan, yang jaraknya paling dekat dengan lembaga keuangan khususnya perbankan yaitu Kelurahan Cempaniga sebagian besar petani berada pada kategori literasi keuangan sedang yaitu sebesar empat puluh responden dari 73 sampel atau 54,79 persen.
Di wilayah Desa Sawaru sebagian besar petani berada pada kategori literasi keuangan rendah dan sedang. Hasilnya berimbang yakni sebesar 34 responden atau 46,58 persen untuk kategori literasi keuangan sedang dan dengan jumlah yang sama yaitu sebesar 34 responden atau 46,58 persen untuk kategori literasi keuangan rendah. Sedangkan di Desa Benteng yang jaraknya paling jauh dari lembaga keuangan khususnya perbankan sebagian besar petani berada pada kategori literasi keuangan rendah yaitu 63 responden atau 86,30 persen.

Berdasarkan analisis komponen indeks literasi keuangan menunjukkan bahwa indeks penyumbang terbesar terhadap indeks literasi keuangan petani adalah indeks sikap finansial. Rata-rata nilai indeks sikap finansial yang dimiliki oleh responden adalah 81,46 persen sementara rata-rata nilai indeks pengetahuan finansial responden adalah 45,41 persen dan rata-rata nilai indeks perilaku finansial responden adalah 45,24 persen. Rata-rata indeks literasi keuangan responden secara keseluruhan adalah 57,37 persen.

\section{Pengetahuan dan Penggunaan Produk dan Jasa Keuangan}

Dari 219 responden, sebagian besar yaitu sebanyak 180 responden pernah mendengar produk tabungan. Sebaliknya, produk mobile banking dan giro merupakan produk keuangan yang tidak banyak diketahui oleh responden. Hanya sebanyak 54 responden pernah mendengar produk mobile banking dan sebanyak 57 responden pernah mendengar produk giro. Sebanyak 101 responden pernah mendengar produk deposito, 120 responden pernah mendengar produk kredit, 94 responden pernah mendengar produk asuransi, 116 responden pernah mendengar produk kartu prabayar (ecard/ATM/Debit), serta 63 responden pernah mendengar produk dana pensiun (tabungan hari tua).

Dari 219 responden, sebagian besar yaitu sebanyak 145 responden pernah atau sedang memiliki tabungan. Sebaliknya, produk giro merupakan produk keuangan yang tidak banyak dimiliki oleh responden yaitu hanya sebanyak 8 responden pernah atau sedang memiliki giro. Sebanyak tiga puluh responden pernah atau sedang memiliki deposito, 62 responden pernah atau sedang memiliki kredit, 37 responden pernah atau sedang memiliki asuransi, 71 responden pernah atau sedang memiliki kartu prabayar (e-card/ATM/Debit), dan tiga belas responden pernah atau sedang memiliki dana pensiun (tabungan hari tua).

\section{Faktor-Faktor yang Mempengaruhi Literasi Keuangan}

\section{Hasil Analisis Regresi Berganda Uji Statistik t}

Uji statistik t, menunjukkan bahwa nilai signifikansi variabel $\mathrm{X} 1(\mathrm{Sig})<\alpha 0,05$ maka hipotesis diterima, artinya variabel $\mathrm{X} 1$ yaitu pendapatan (rupiah) berpengaruh signifikan terhadap indeks literasi keuangan petani dengan koefisien pendugaan sebesar 3.326E-

6 (0.003326). Hal ini berarti peningkatan pendapatan sebesar 1 persen akan meningkatkan literasi keuangan sebesar 0.003326 , ceteris paribus.

Nilai signifikansi variabel $\mathrm{X} 2(\mathrm{Sig})>\alpha 0,05$ maka hipotesis ditolak, artinya variabel X2 yaitu usia (tahun) dengan koefisien pendugaan sebesar 0.108. Hal ini berarti variabel usia tidak berpengaruh signifikan terhadap indeks literasi 
keuangan petani. Hal ini menunjukkan bahwa tinggi rendahnya indeks literasi keuangan tidak bergantung kepada usia seseorang.

Nilai signifikansi variabel X3 (Sig) $<\alpha 0,05$ maka hipotesis diterima, artinya variabel X3 yaitu tingkat pendidikan (tahun) berpengaruh signifikan terhadap indeks literasi keuangan petani dengan koefisien pendugaan sebesar 0.735. Hal ini berarti peningkatan satu tahun lama pendidikan akan meningkatkan literasi keuangan sebesar 0.735, ceteris paribus. Semakin tinggi tingkat pendidikan seseorang maka akan semakin tinggi tingkat literasi keuangannya.

Nilai signifikansi variabel X4 (Sig) $<\alpha 0,05$ maka hipotesis diterima, artinya variabel $\mathrm{X} 4$ yaitu dummy preferensi risiko berpengaruh signifikan terhadap indeks literasi keuangan petani dengan koefisien pendugaan sebesar

6.084. Hal ini berarti responden yang merupakan pengambil risiko (risk taker) memiliki indeks literasi keuangan yang lebih tinggi dibandingkan dengan responden yang penghindar risiko (risk averse) dengan selisih sebesar 6.084.

Nilai signifikansi variabel X5 (Sig) $<\alpha 0,05$ maka hipotesis diterima, artinya variabel X5 yaitu jarak tempat tinggal ke lembaga keuangan terdekat $(\mathrm{Km})$ berpengaruh signifikan terhadap indeks literasi keuangan petani dengan koefisien pendugaan sebesar - 0.608. Hal ini berarti peningkatan jarak tempat tinggal responden ke lembaga keuangan terdekat sebesar satu Km akan menurunkan indeks literasi keuangan sebesar 0.608, ceteris paribus.

Hasil penelitian menunjukkan bahwa empat variabel bebas yang berpengaruh secara signifikan terhadap variabel terikat adalah variabel tingkat pendapatan, tingkat pendidikan, dummy preferensi risiko dan jarak ke lembaga keuangan, sehingga hasil penelitian sesuai dengan hipotesis awal. Sedangkan yang tidak sesuai dengan hipotesis adalah variabel usia tidak berpengaruh signifikan terhadap variabel terikat literasi keuangan.

\section{Uji Statistik F}

Pengujian kelayakan model dilakukan dengan menganalisis nilai signifikansi. Uji statistik $F$ dengan nilai signifikansi $($ Sig) $<(\alpha) \quad 0,05$ maka hipotesis diterima. Hal ini menunjukkan bahwa variabel bebas yang digunakan yaitu tingkat pendapatan, usia, tingkat pendidikan, dummy preferensi risiko, dan jarak tempat tinggal ke lembaga keuangan terdekat secara bersama- sama/simultan berpengaruh nyata terhadap variabel terikat yaitu literasi keuangan.

Menghitung Koefisien Determinasi $\left(\mathrm{R}^{2}\right)$ Koefisien determinasi yang digunakan dalam penelitian ini adalah $\mathrm{R}$ Square. Hasil pengolahan data untuk melihat faktor-faktor yang mempengaruhi tingkat literasi keuangan petani, dengan menggunakan metode analisis regresi linear berganda, uji koefisien determinasi $\mathrm{P}^{\prime \prime}$ menunjukkan $\mathrm{R}$ Square sebesar 0.438, yang dapat diartikan bahwa variabel bebas yaitu tingkat pendapatan, usia, tingkat pendidikan, dummy preferensi risiko, dan jarak tempat tinggal ke lembaga keuangan terdekat mampu menerangkan 43,8 persen terhadap variabel terikat yaitu literasi keuangan dan sisanya 56,2 persen dijelaskan oleh variabel-variabel lain yang tidak diteliti.

\section{Simpulan}

Berdasarkan hasil penelitian dan pembahasan yang telah diuraikan sebelumnya, maka dapat diambil kesimpulan sebagai berikut:

Mayoritas petani di lokasi penelitian termasuk pada kategori literasi keuangan yang rendah yaitu sebesar 122 responden.

Indeks sikap finansial menjadi penyumbang terbesar indeks literasi keuangan petani. Rata-rata indeks sikap finansial yang dimiliki petani adalah sebesar 81,46 persen sementara ratarata nilai indeks pengetahuan finansial responden adalah 45,41 persen dan rata-rata nilai indeks perilaku finansial responden adalah 45,24 persen.

Sebagian besar responden telah mengenal dan pernah atau sedang menggunakan produk keuangan tabungan tetapi penggunaan produk jasa keuangan lainnya masih terbilang sedikit. Petani masih membatasi penggunaan kredit jika mengalami kesulitan keuangan. Dalam mengelola keuangan seperti meminjam dana dalam jumlah tertentu petani lebih mengandalkan pinjaman dari teman atau keluarga sedangkan untuk pinjaman yang cukup besar banyak petani yang sudah melakukan pinjaman di bank tetapi membatasi jumlah pinjaman (kredit). Sedangkan untuk produk dan jasa keuangan lainnya seperti asuransi dan dana pensiun petani masih terbatas pada kesediaan dananya. Masih banyak petani yang memiliki pendapatan yang rendah sehingga belum bisa menyalurkan pendapatannya ke produk keuangan tersebut. Untuk produk deposito, giro, dan mobile banking petani masih belum terlalu memahami dan sebagian besar masih butuh informasi mengenai produk keuangan tersebut.

Penelitian ini berkontribusi dimana hasil menunjukkan bahwa faktor-faktor yang mempengaruhi tingkat literasi keuangan petani adalah tingkat pendapatan, tingkat pendidikan, preferensi risiko dan jarak ke lembaga keuangan. Sementara variabel usia tidak memiliki pengaruh terhadap literasi keuangan.

\section{Ucapan Terima Kasih}

Tim penulis dapat menggunakan bagian ini untuk memberikan ucapan terima kasih pada berbagai pihak yang membantu kesempurnaan penulisan artikel (dosen pembimbing yang dicantumkan sebagai penulis artikel tidak perlu diberi ucapan terima kasih). Berbagai pihak tersebut bias (a) pihak yang memberikan sponsorship dalam penelitian, (b) pihak yang telah melakukan proof reading artikel ini, dan (c) pihak yang membantu tersedianya data. Teknik penulisan bagian ini sama dengan teknik penulisan bagian sebelumnya. Bagian ini disajikan dalam bentuk paragraph (yang terdiri atas 5-10 baris). Subbagian ini tidak wajib dituliskan.

\section{Referensi}

Anwar, A.I., Kusuma, J., Rahmatia, Fatmawati, Usman, A., Hamrullah. 2006. Perilaku dan Preferensi Masyarakat Sulawesi Selatan Terhadap Bank Perkreditan Rakyat (BPR), (Online), (https:/www.researchgate.net/publication/237672

424_Perilaku_Dan_Preferensi_Masyarakat_Sulawesi_Selatan_Terhad ap_Bank_Perkreditan_Rakyat_BPR diakses 16 Mei 2018).

Arikunto, S. 2006. Prosedur Penelitian Suatu Pendekatan Praktik. Jakarta: PT. Rineka Cipta.

Atkinson, A., and Messy, F. 2012. Measuring Financial Literacy: Results of the OECD/International Network on Financial Education (INFE). 
OECD Working Papers on Finance, Insurance and Private Pensions, (15).

Chen, H. and Volpe, R.P. 1998. An Analysis of Personal Financial Literacy Among College Students. Financial Service Review 7(2): 107-128.

Firdaus dan Sunarti, E. 2009. Hubungan antara Tekanan Ekonomi, Manajemen Keuangan, dan Mekanisme Koping dengan Kesejahteraan Keluarga Wanita Pemetik Teh. Jurnal Ilmu Keluarga dan Konsumen 2(1): 21-31.

Giffari, A.S. 2018. Analisis Literasi Finansial Mahasiswa Fakultas Ekonomi Universitas Islam Indonesia. Yogyakarta: Fakultas Ekonomi Universitas Islam Indonesia.

Mabyakto, G. 2017. Analisis Tingkat Literasi Keuangan Mahasiswa. Yogyakarta: Program Studi Manajemen Jurusan Manajemen Fakultas Ekonomi Universitas Sanata Dharma.

Otoritas Jasa Keuangan. 2015. Strategi Nasional Literasi Keuangan Indonesia. Jakarta: Otoritas Jasa Keuangan.

Otoritas Jasa Keuangan. 2016. Survei Nasional Literasi Dan Inklusi Keuangan 2016. Jakarta: Otoritas Jasa Keuangan. Otoritas Jasa Keuangan. 2017. Literasi Keuangan. Financial Literation Discussion, (Online), (https://www.ojk.go.id/id/kanal/edukasi- dan- perlindungan-konsumen/Pages/Literasi- Keuangan.aspx diakses 22 Desember 2018).

Otoritas Jasa Keuangan. 2017. Strategi Nasional Literasi Keuangan Indonesia (Revisit 2017). Otoritas Jasa Keuangan: Jakarta.

Ravikumar, R., Sivakumar, S.D., Jawaharlal, M., Palanichamy, N.V. dan Sureshkumar, D. 2013. Assessment of Farm Financial Literacy among Jasmine Growers in Tamilnadu, India. Journal of Developing Country Studies 3(13): 68.

Saptia, Y. 2017. Sumber Pembiayaan Terbatas Akibatkan Produktivitas Petani Rendah. Biro Kerja Sama, Hukum, dan Humas LIPI (Online), (http://lipi.go.id/berita/sumber-pembiayaan- terbatas-akibatkanproduktivitas-petani- rendah/19058, diakses 29 Desember 2018).

Yarasevika, S. 2016. Evaluasi Tingkat Literasi Keuangan Petani Padi Dan Hortikultura Di Kabupaten Tasikmalaya Dan Garut. Bogor: Departemen Ilmu Ekonomi Fakultas Ekonomi Dan Manajemen Institut Pertanian Bogor.

Yushita, A.N. 2017. Pentingnya Literasi Keuangan Bagi Pengelolaan Keuangan Pribadi. Jurnal Nominal 4(1): 14.

Yuwono, M., Suharjo, B., Sanim, B., Nurmalina, R. 2017. Analisis Deskriptif Atas Literasi Keuangan Pada Kelompok Tani. Jurnal Ekonomi dan Keuangan 1(3): 408-428. 